\title{
Energy security as a public good
}

\author{
Zdzisław Szalbierz ${ }^{1, *}$, Edyta Ropuszyńska-Surma ${ }^{2}$ \\ ${ }^{1}$ Wrocław University of Science and Technology, Faculty of Computer Science and Management, \\ Wyb. Wyspianskiego 27, Wroclaw, Poland \\ ${ }^{2}$ Wrocław University of Science and Technology, Faculty of Computer Science and Management, \\ Wyb. Wyspianskiego 27, Wroclaw, Poland
}

\begin{abstract}
Energy security is discussed as a multi-dimensional and complex category displaying features of a public good. Such an approach to energy security indicates that there are complex interdependencies between sector entities, consumers and public administration. The purpose of the paper is to identify and analyze relations between energy security and the policy of the state aiming at satisfying consumer demands. The key role here is played by legal and institutional regulations which have impact on all the defined dimensions of energy security.
\end{abstract}

\section{Introduction}

This article aims to identify and analyze the relations between energy security and the state policy in its responsibility for meeting the need for a variety of energy forms which households, businesses and public entities report at a particular time and place. The starting point for the discussion is the thesis according to which in Poland we are currently outside the realm of energy security, and we lack clear objectives for the protection of the environment (this relates especially to the targets for $\mathrm{CO}_{2}$ emissions). The applied regulation instruments are becoming ineffective - among other things due to the lack of clearly defined objectives and the lack of a consistent long-term policy towards various stakeholders, e.g. prosumers.

In this context it is worthwhile to ask three questions:

1. What do we understand under the notion of energy security?

2. Is energy security a public good (common/free good) and in what sense is the state responsible for it?

3. What role does the legal and institutional regulation fulfill in reaching a higher level of energy security?

\section{The nature of energy security}

In recent years, after a relatively quiet period, there is again concern about the ability to satisfy energy needs by energy systems. This stems above all from the risk of interruptions of delivery (at determined times) in electricity and gas grids. The conviction that there is an

* Corresponding author: edyta.ropuszynska-surma@pwr.edu.pl 
increasing risk of an energy deficit at specific times and places, and energy security has become the subject of increasingly intense discussions among scientists, economic activists and politicians. In Poland, two significant trends are observed. The first concerns the steady shrinkage in recent years of power reserves in relation to the maximum demand. The second consists in the increase of the peak demand, for example, on 23 June 2016 the record of the summer power demand was beaten, amounting to 22, $634 \mathrm{MW}$, while on 21 June 2013 the level was 1,033 MW less [1].

Energy security is becoming particularly important, however, it is defined in many different ways, taking into account various aspects.

A widely accepted general definition of energy security (security of electricity supply) has been "the ability to meet the demand for electricity, heat and gas in market conditions in terms of quantity and quality at the lowest possible price, resulting from the balance between the supply and the demand, while maintaining environment protection conditions [2].

The Union for the Co-ordination of Transmission of Electricity (UCTE) and the European Transmission System Operators (ETSO) see energy security from the angle of the technical operation of the power system. As a superior notion [3] the system reliability was adopted, understood as its capacity to supply customers with the necessary amount of energy in accordance with certain standards. At the level of the transmission and distribution grids the measures of reliability can be e.g.: the frequency, duration, and the likelihood of interruptions in deliveries, transmission and energy production. Within the reliability of the system two aspects are distinguished: adequacy as the system's ability to supply power and energy to cover the aggregate demand of consumers at any time, including planned or reasonably expected switch-offs of system components (standards of quality and reliability) and security - the ability of the power system to withstand sudden disturbances such as short circuits or unexpected loss of system components as a result of emergency shutdowns, natural (technical) disasters or terrorist attacks.

Polish Energy Policy until 2030, adopted by the Council of Ministers on 4 January 2009, defines energy security as "a state of the economy allowing to cover the current and prospective demand for fuels and energy, in a technically and economically justified way, while minimizing the negative impact of the energy sector on environment and social conditions" [4].

Finally, it is worthwhile to cite the definitions of energy security by T. Jamasb and M. Pollitt. According to these two eminent specialists from the MIT, since the energy market is undergoing liberalization and energy security has become multidimensional it is necessary to redefine the concept. They suggest in this context that in light of the liberalization of markets, the role of enterprises owned by the State Treasury, conditions of operation of the business environment (outside of the energy sector) and households the concept of energy security should be referred to the risk of a failure in supplying energy and the increased costs accompanying this risk [3]. As a result, the security of energy supply becomes a risk management strategy with strong references to cost effectiveness associated with both energy supply and energy demand. The question is how to interpret a situation in which the imbalance between the supply and the demand for important energy carriers (e.g. natural gas, electricity) is so big that it leads to a loss much larger than it would have cost if the equilibrium were taken care of in advance.

Thus, depending on the scope and scale of the analysis of energy security it is difficult to fully accept some definitions, because:

- $\quad$ on the one side the chain of the factors determining the level of energy security goes far beyond the area of the economy so that "energy security" is not a feature of the "state of the economy" only but also the result of a number of external conditions of its operation,

- on the other hand - to the recipient suddenly deprived of power it is, in fact, all the same whether the cause of this condition is outside the country or if it is the result of negligence 
of his municipality or the company supplying fuel, electricity or heat to him; he is primarily interested in the question when the power is going to be restored, and what will be the possible financial consequences of the interruption, and, finally, what can you protect yourself against a repeated emergency like this.

It can be said that the elements determining the level of energy security constitute a chain whose individual parts are [3]:

1. access to primary energy carriers at a level that allows to meet the demand taking into consideration the transportation technology of primary carriers,

2. technologies of transformation of primary carriers into usable carriers,

3. long-distance transport technologies of usable carriers,

4. short-distance transport technologies of usable carriers,

5. mechanisms of financing the operations and development of energy sectors.

Each of these categories is subject of:

a) an economic analysis- ability of the economy to finance it, including the cost for limiting the environmental impact,

b) an environmental analysis - the level of the impact on the environment in the part that at present cannot be valued in economic terms,

c) the level of risk of interruptions including the interruptions stemming from political and military actions of other states,

d) an analysis of the threat of terrorist attacks,

e) extent of risks stemming from an interruption,

f) availability of procedures preventing interruptions.

Each category is also subject to an individual differentiation because of the specific nature of each carrier, both of primary energy and usable carriers, as well as the time horizon of the analysis.

It thus becomes clear that a deeper analysis of "energy security" leads to the conclusion that it is to far a simplification to ascribe to this notion the structure of a simple chain of relations. It has the structure of a multi-dimensional matrix, thus it is so tricky to attempt a sectional analysis.

Such many aspects of the notion of "energy security" mean that the array of risks that it is subject to, and of actions that need to be taken to protect it, is very differentiated, but also the responsibility for the state of energy security does not lie upon just one or a few entities. Rather, the statement seems substantiated that in Polish conditions energy security cannot be a matter dealt with only by entities of the energy sector since experience teaches us that they are not able to cope with the problem of the lack of energy security on their own.

The task of protecting energy security in its multifaceted aspects must thus be given to various institutions in the political, economic and social arena - in proportion to their role and competences: the highest authorities of public administration, its local authorities, energy sector companies, and the consumers. It is thus of particular importance to face the problem of the coordination of various actions at various levels since many aspects of energy security that are correlated with each other can be solved in an alternative way. In many cases, however, the adoption of one option excludes the rational application of another [3].

\section{Energy security as a public/common good}

There is no possibility of providing a clear definition of energy security as a good that would have a public/common character although intuitively we assume that being public/common is its important feature. In textbooks of classical economics energy security is not mentioned as a good, as opposed to national defense or the judicial system which are exhibited as model examples of purely public goods. Not everyone is able to perceive the category of public goods. An illustration of this statement can be the Polish PWN Encyclopedia of 2002 which 
does not contain the term of "public good". However, it contains the terms of a free good and a common good. Free is a good whose price equals zero. If we adopt this definition then free goods do not exist, thus they have become a historical category. A common good is a term for a collective value generated by communities to satisfy their individual interests [5]. A common good is interpreted differently depending on the approach. It seems that it also encompasses the interests of the state. The way how these interests are perceived depends on political convictions, and its content seems to be connected with its perception by an individual and the government. In this context it is worthwhile to fill this gap in relation to the notions of public good and energy security.

In the preceding bullet point the term of energy security is defined as a multi-aspect and complex category. For the sake of clear argumentation in our further analysis is has to underscored that the authors do not identify the notion of "energy security" with the service of supply of power (or any other carrier of energy) to the consumer. Energy security is according to the economic nomenclature - one of thee many needs that is not satisfied by the supplier of the given energy carrier but by complex additional services, mostly invisible to the consumer. Such services, closely connected with the elements determining the level of energy security, include among others [6]:

- collection and monitoring of data on the demand for the generation capacity, the technical and economic state of the infrastructure,

- coordination of activities in the energy sector (including matching the supply and the demand in various periods),

- forecasting the directions of development of the technologies of production, storage, transport, distribution and use of energy,

- creation of the basis for an efficient use of energy.

From the point of view of the economics a public good is linked with a category of needs that can be satisfied by specific goods that are not subject to marketplace rules $[7$, p. $549 ; 8$, p. $150 ; 9$, p $131 ; 10$, p. 59 , p. 126]. In most economies the provision of public goods is the matter of the state, because - as stated earlier - they are not provided by the market. But the state does not have to be their supplier. The contemporary empirical and theoretical research indicates that both in the past ${ }^{\dagger}$ and in the present times communities, mostly local ones, have voluntarily taken initiatives of joint production and/or provision of public goods (e.g. combating crime) [10, pp. 86-87 ]. Such activities are associated with values such as social capital, or social ties. In the context of energy security, these initiatives may cover a relatively limited geographical area, and a key role in such projects will be played by local administration. But energy security should be seen in a much wider context than only through the prism of the local community. Therefore, the role of state bodies and its law regulations are crucial [11, p. 89-90, 95-96].

As noted earlier, the allocation of goods into various categories is not always clear. An important contribution to economics in this area was made by the classification of goods, proposed by Musegrave, Samuelson, and then developed by "club goods" of Buchanan. The division is based on two criteria: (1) the competition for the good among consumers (2) the possibility of being excluded from its consumption. According to this classification pure public goods are those where you can not exclude an entity from their consumption or such an exclusion is very expensive, and when consumers do not compete for the given good. From the definition of the public good results that "consumers (users) do not have to buy

\footnotetext{
$\dagger$ Hume noted in the first half of 18 th century that neighbors may agree on the melioration of a meadow but that there is the risk that they will not agree on this because each of them will try to exploit the others. Therefore, the role of a judge, who would care for the common interest, was so important to Hume [Hume, 1739, p. 1911, 539; op. cit. 10, p. 37].
} 
them" $[8$, p. 168]. This does not mean that the cost of their production is zero, because the public good is not for free. Public goods, especially those provided by the state ${ }^{\S}$, but not necessarily produced by it, are financed by taxes. In economics, the tax price determines the amount of additional tax corresponding to the costs which must be incurred in the event of increasing the production/delivery of a public good to different people. For this purpose a survey can be carried out among customers asking them "how much amount their expenditure on the public good would be, if there were a set price for each additional unit of the good" [8, p.168]. On this basis, you can determine the rate of substitution e.g. of a private good with a public good, and that informs you how much private goods or what number of units of a private good the consumer is willing to give up to increase the consumption of the public good by a unit [8, p.168-171]. In the same way research has been carried out that allows to calculate the so called "willingness to pay" (WTP) for the delivery/production of a unit of a specific good. An example would be to estimate the so-called willingness to pay for ensuring the continuity and reliability of electricity supply [12] or energy produced from renewable sources [13].

In addition to the lack of competition for the public good and the inability to exclude anyone from its consumption another feature of public goods are their positive external impacts, often constituting the main value of such goods [9, p. 132]. Ensuring energy security, as mentioned before, through the already mentioned package of services meets this criterion.

It follows that energy security on the one hand seemingly "escapes" the concept of the public good or the common good, on the other hand - especially on the international and national level, and not to a small extent also on the regional level - it does not bend to the rules of the market, and even to the principles of responsibility for security through companies that are public and are under state control. And the state control is implemented through legal and institutional regulations. We can at this point refer to the question that was repeatedly cited by Musgrave and referred to the availability of public goods - he believes that it is a political process "by which such goods are made available, rather than a process of public production " [10, p.37].

\section{The Role of regulations}

In the literature, it is emphasized that since 1990 regulation has been seen as a factor which plays a key role in the implementation of market reforms in the energy sector by improving the efficiency of investment in both the generation sub-sector and power grids, as a factor that ensures the effective operation and the possibility of competition via the TPA rule. The results of this regulation seem to be positive, especially in Great Britain [3].

From the point of view of the objectives of economic efficiency, proper regulation in the energy sector should play a particularly important role in providing incentives for energy supply security. However, in some countries or regions, it is the regulations that is pointed out as a reason for blackouts. The classical example is the energy crisis in California in 2000. The report of The California Public Utilities Commission (SPUC) pointed out that the cause of the crisis in California were too high prices and external errors of state authorities

\footnotetext{
\# A similar approach is presented by Samuelson and Nordhaus for whom public goods are goods who benefit the whole community regardless of whether individual persons want to acquire them or not" [7, p. 549].

$\S$ Throughout centuries two models of the decision-taking process on the delivery of public and private goods have developed, i.e.: (1) reaching a social consensus as a result of a vote (the concept by Wicksell of 1896 r.), (2) appointing a judge who on the basis of his preferences will determine the optimum allocation of resources between private and public goods (Samuelson, 1954) [10 p. 38-41].
} 
inhibiting the development of new production capacities, which were the result of regulations introduced in 1996 and 1998. [14]. In this context, the aim of regulation is to ensure stimulators (incentives) for sufficient capacity and efficiency of both the grids and production capacities consuming different types of primary energy. The purpose of regulation is - from an economic point of view - apart from the security of energy supplies, a stability of prices charged to consumers, both in the high and low voltage range. At a higher level of generalization the aim of regulation will be energy security in the context of climate change, international exchange of energy carriers, as well as the proliferation of nuclear materials.

In the light of the foregoing it has to be stated that regulation, through the use of regulatory instruments that are effective and ensure efficiency, can and should play an important role in ensuring energy security in the short, medium and long term. The purpose of this text cannot be to offer instruments that can be used. The subject of this paper can merely be to identify the challenges and trends and to draw attention to the need for changes to the existing regulations in Poland.

From the perspective of regulation attention should primarily be paid to the classification of the factors affecting the level of energy security. However, it seems that so far, some of them are, in fact, have only been the means to achieve the goal, and the actual causative factors have not been defined.

The result of the evaluation of the level of energy security depends on three questions:

1. From which perspective is the evaluation done - that of a state, region, commune, industry or an individual consumer?

2. To what form of energy demand does it apply (what demand of the consumers does it relate to)?

3. What is the time horizon of the evaluation?

The concept of energy security used for the purpose of energy policy of the state must take into account - if it is to perform the desired function in the right way - both the global aspect as well as the local one, without neglecting any of the intermediate links, and extend over the longest possible time horizon. The USA may be a good example of the latter as it has developed its energy policy for the time horizon of 100 years. The EU is going in this direction, unfortunately lagging far behind the USA since its forecast horizon in this field is about 25 years [2].

As it was emphasized above the measure of energy security is the reliability of supplies at an economically justified level of prices and an impact on the natural environment limited to an economically and socially acceptable level. It is easy to observe that it is a measure constructed from the point of view of the both a local consumer, connected to the power system, in particular somewhere on the periphery, and the 'collective consumer', which are individual fields of social life (such as communications, banking, health care, army, police, administration, etc.), and the national economy perceived as a whole. Not without significance in this case is the fact that the discussions on the international forum dedicated to the issues of energy security in the presented meaning are conducted under the banner of the 'security of supply', regardless of whether they are focused on ensuring Europe's longterm access to oil and gas deposits, or on threats to the stable operation of transmission systems in the conditions of natural disasters, and the prevention of their effects.

The problem of energy security in Poland is becoming more urgent. Meanwhile, the entities in the energy sector, especially in the electricity sector can not find methods and tools for the efficient and effective investment. Decisions on new investment projects are postponed, and the capacities derived from units to be installed in the foreseeable future will not satisfy the growing demand - their example may be the unit with a capacity of $858 \mathrm{MW}$ in Bełchatów and the long-debated two similar units in Opole. Due to the high regulatory and price risk, in the period 2010-2014 energy companies abandoned the construction of 10 new generation units. The condition of the present generating units is a reason for concern because 
$50 \%$ of the NPS capacity are units built in the 70 s and before. In 2050 out of the current production capacity only $5 \mathrm{GW}$ will still be in operation $[15, \mathrm{p} .8]$. Energy companies have promised to build 11 new units until 2019, 10 of which will be units under the control of the State [15, p.11]. It means that other companies do not have sufficient incentive mechanisms to take up such activities. Other investment projects are at the stage of prolonged discussions, an example of which can be the construction of a nuclear power plant. Paradoxically, the new capacities are the much contested wind farms (4886 MW in 2015) [16, p. 46]. In Poland the RES capacity equilled $6930 \mathrm{MW}$ and most of it was in the form of wind turbines. Next part of this capacity was contained in hydro generators ( $964 \mathrm{MW}$ in 2015) and biomass (740 MW in 2015).In 2015 we could observe the increase in solar energy capacity because the capacity of solar plants totalled $27 \mathrm{MW}$ in 2014, but it equalled $108 \mathrm{MW}$ in 2015 [16, p. 46]. In 2014 in Poland the share of the RES was $11.9 \%$ of the primary energy, while in Germany this value totalled 30\%. For years from 2011 to 2014 in Poland the share of the RES increased by 1\% (from $10.9 \%$ to $11.9 \%$ ), while in Germany by $6 \%$ (from $24 \%$ to $30 \%$ ). [16, p. 24]. In 2015 363390 TJ came from the RES 363390 TJ which was $12.7 \%$ of total primary energy in Poland. Most of them came from biomass $(72,22 \%)$ and from wind and bio-liquid fuels (respectively $10.76 \%$ and 10,78\%) [16, p. 32]. We observe in Poland the increase in the RES, as measured by the capacity and generation. However, renewable energy generation (excluding wind turbines) has very little importance in Poland, and its development is very conservative, without clearly formulated goals, unlike in the Germany where power generation is developing in a multi-faceted way with the priority given to renewable energy. Nowadays, Germany realize policy called 'Energiewende', which is a complex program related to, among others the development of RES and the improvement in the efficiency of generation and consumption of all kinds of energy

This situation is confirmed by a report of the Supreme Control Chamber NIK [15], which found indeed that the current security, as guaranteed by companies of the sector, is provided in due degree, but efforts to ensure energy security in the long run are insufficient. Furthermore, alarming forecasts indicating a continuation of the upward trend in the maximum demand for power up to $40 \mathrm{GW}$ in 2035 and $41-42 \mathrm{GW}$ in 2050 , and the demand for electricity from approx. $159 \mathrm{TW} \cdot \mathrm{h}$ in 2015 to $230 \mathrm{TW} \cdot \mathrm{h}$ in 2030 are emerging. [15, p. 8].

Energy grids, both transmission and distribution ones (for electricity and gas) are a natural monopoly and are subject to regulation which aims to guarantee the public interest (good). In this case, this interest (public good) manifests itself in the efficient and effective (in this article, these terms have praxeological meaning) work management of energy grids. It can be evaluated if, in practice, the idea of the public interest is realized or if, following J. Stiglitz, it should be assumed that in this case we have to do with the phenomenon of regulatory capture which means that a regulation is "captured" (perhaps in a big portion) by the regulated entities [17].

In this short article it is impossible to exhaust all topics of energy security and of the nature of regulation. We can only put forward certain hypotheses, cite some literature and practical examples to support them.

We allow ourselves to formulate the following theses:

1. The national energy generation, especially the energy grid is in the state of a substantial and increasing imbalance in terms of the security of energy supply. This applies to both power transmission and distribution systems as well as the generation sub-sector.

2. Regulations in the field of energy security are dispersed among international actors (within the EU) and numerous national ones. There is an apparent lack of co-ordination of regulatory tools used by individual entities. As a result, the existing regulations do not meet the requirements of efficiency and effectiveness, and they do not guarantee a reliable supply of energy. 
In recent years in Poland there have been serious disruptions in the supply of electricity (Szczecin 2008, the area of Podkarpacie 2010, August 2015). Despite many investment projects into the grid, the state of the transmission and distribution networks is worsening. In addition, some urban areas are supplied basically via one transmission line, carrying enough power now but whose failure could cause a serious disruption in energy supply. According to the classical principle of risk protection (in this case it is the risk of a blackout), one should aim to diversify the sources of supply. This applies mainly to large urban agglomerations. Such a situation had for a relatively long period of time concerned Wroclaw, only since 2010 intensive effort has been made to diversify and expand connections. Currently, the security of supply of electricity for the city of Wrocław is rated to be at a good level [18]. An increase in the degree of diversification of power sources can also be achieved by expanding local dispersed energy sources, including renewable energy sources, which can be located directly at the destination. This idea is associated both with the concept of Smart Grids and the emergence - in Poland a still new - entity on the energy market - the so-called prosumer, as well as with the concept of ecological safety. Smaller towns, and mainly rural areas can choose from a catalog of more renewable energy technologies than large urban agglomerations. ${ }^{* *}$

Table 1 shows the basic conditions for ensuring energy security on the national scale as well as - to a significant degree - in the region.

Table 1. Energy security conditions on the state and regional level

\begin{tabular}{|c|c|}
\hline Basic conditions of energy security & Additional conditions \\
\hline Sustained energy balance & Preserving economic security \\
\hline $\begin{array}{c}\text { Availability and sufficiency of infrastructure } \\
\text { for processing, storage and distribution of } \\
\text { fuels and energy }\end{array}$ & Preserving ecological and process safety \\
\hline Diversification of energy carrier sources & Resistance to random and intentional threats \\
\hline
\end{tabular}

Source: [19]

The experience shows that periodically there may be serious discrepancies between the amount of offered energy (electricity, gas, heat from centralized sources) and the demand of the consumers that lead to losses on the part of the consumers (economic, financial, political and social) whose amount often significantly exceeds the expenditure for the production and transmission of energy. The above mentioned report by the NIK states that "the value of social losses caused by insufficient energy supplies in the years 2020-2030 can reach (....) 70 billion PLN, and the overall expenditure on the implementation of the above system solutions, e.g. power markets - is expected to be no more than 3-5 mln PLN" [15, p. 10]. It can be thus stated that from the economic point of view, if the necessary amount of energy is not delivered, it leads to losses whose height may significantly exceed the cost of production and delivery of the energy to consumers and be significantly higher than the expenditure necessary to implement new services ensuring the continuity of supply. Energy security therefore, also includes situations in which there are no physical shortages of energy but there are problems with its delivery, which in turn causes opportunity cost, the amount of which exceeds the costs incurred to produce and be prepared to make electricity available [17].

In recent years the importance of the guarantee of energy security has increased due to the occurrence of significant disruptions in the mechanism of energy supply. In real-life economy the activities of the entities of the energy sector in the scope of energy security supply are often not effective enough. Therefore there is an urgent need for harmonization

\footnotetext{
${ }^{* *}$ See the results of the project ENERGYREGION (www.energy-region.eu).
} 
with other entities, and above all with local government bodies, non-governmental organizations, as well as large, medium and small customers to guarantee a safe and effective matching of the amount of the produced energy with the demand for it [17].

\section{Summary}

In the context of the presented considerations there emerges an important question: how can the operation of the energy system and its regulation reduce the risk of energy deficit on a mass scale assuming that energy security is a public good? While trying to find an answer to this question we should formulate the basic objectives of regulation. The first is the construction of new power capacities, the second will be effectively functioning transmission and distribution networks; and the third - the relation between the operation of transmission and distribution networks and the "behavior of consumers."

In terms of the first objective, i.e. the construction of new generation capacities we have to distinguish among others the following factors: (1) identification of investment locations and obtaining permits for construction, (2) determination of the primary fuel and the effects of its use for the environment and economy (mainly the cost structure, keeping in mind that some renewable energy sources have variable costs close to zero, and therefore no marginal costs), (3) determination of the technical and economic parameters of the operation of the new power plant (4) transmission of power over the transmission system.

The second objective, i.e. an effective transmission and distribution grid should include: (1) investment projects necessary and sufficient to ensure the security, (2) building an effective structure of the sector and unbundling of the generation, transmission, distribution and marketing, (3) diversification of energy sources to help ensure competition, (4) legal, economic and financial responsibility for a breach of security both on the demand and supply sides, (5) international, national and regional coordination of regulatory tools.

The third objective, i.e. the relationship between the operation of the network and the "behavior of consumers" should include: (1) activation of processes of energy saving on the so-called demand side, (2) development of systemic mechanisms allowing for the participation of energy consumers, so that a flattening and/or a shift of the load curve occurs, (3) development of intelligent networks (Smart Grids) and flexible supply of energy taking into account micro-generation and dispersed generation, (4) active impact on the demand for energy by the public sector, (5) adaptation of legal regulations to incorporate the need for saving energy, (6) implementation of new - effective forms of management and ownership structure of the transmission and distribution grids.

It should be emphasized that energy security requires systemic instruments allowing for risk sharing among all energy market participants. The energy policy and legal create more or less comfortable conditions for modernization and making new investments.

\section{References}

1. Roczne raporty PSE o Krajowym Systemie Elektroenergetycznym, available www.pse.pl (18.08.2016)

2. Doktryna zarządzania bezpieczeństwem energetycznym, Ministerstwo Gospodarki i Pracy, Warszawa (maj 2004)

3. T. Jamasb, M. Pollitt, Security of supply and regulation of energy networks, Energy Policy 36 (2008)

4. Polityka energetyczna Polski do 2030 roku. Załacznik do uchwały nr 202/2009 Rady Ministrów z 10 listopada 2009 r.

5. Wielka Encyklopedia, Wydawnictwo Naukowe PWN, Warszawa (2002) 
6. Z. Szalbierz, E. Ropuszyńska-Surma, Bezpieczeństwo energetyczne w układzie regionalnym, Systems: Journal of Transdisciplinary Systems Science (2008)

7. W.D. Nordhaus, P.A. Samuelson, Ekonomia t.1, Wydawnictwo Naukowe PWN, Warszawa (2004)

8. J.E. Stiglitz, Ekonomia sektora publicznego, Wydawnictwo Naukowe PWN Warszawa (2013)

9. N. Acocella, Zasady polityki gospodarczej, Wydawnictwo Naukowe PWN, Warszawa (2002)

10. J.M. Buchanan, R.A. Musgrave, Finanse publiczne a wybór publiczny. Dwie odmienne wizje państwa, Wydawnictwo Sejmowe, Warszawa (2005)

11. Marszałek, M. Swoboda działalności gospodarczej wytwórcy - sprzedawcy energii elektrycznej, Wyd. C.H. Beck, Warszawa (2015)

12. D. Layten, K. Moeltner, The Cost of Power Outages to Heterogenous House-holds, Applications of Simulation Methods, Kluver Acd. Press (2005).

13. R. Scarpa, K. Willis, Willingness-to-pay for renewable energy: Primary and discretionary choice of British households' for micro-generation technologies, Energy Economics 32 (2010)

14. L. Steadman, Energy Bills: Temporary Measures Versus Long-Term Relief, Pacific Research Institute for Public Policy 57 (22.08.2000)

15. Najwyższa Izba Kontroli, Zapewnienie mocy wytwórczych $w$ elektroenergetyce konwencjonalnej. Informacja o wynikach kontroli. KGP-4101-001-00/2014, Nr ewid. 17/2015/P/14/018/KGP (4.03.2015)

16. Główny Urząd Statystyczny, Energia ze źródeł odnawialnych w 2015 r., Warszawa (2016).

17. A. Bieńkowska, E. Ropuszyńska-Surma, M. Bogrosz-Koczwara, Z. Szalbierz, Kształtowanie sieci wspótpracy na rzecz bezpieczeństwa energetycznego Dolnego Ślaska ze szczególnym uwzględnieniem aspektów ekonomiczno-społeczych, Politechnika Wrocławska seria SPR 3, Wrocław (2009)

18. Aktualizacja założeń do planu zaopatrzenia $w$ ciepło, energię elektryczna i paliwa gazowe dla obszaru Gminy Wroctaw (wersja uzupetniona i poprawiona) (27.12.2012)

19. G. Bartodziej, M. Tomaszewski, Polityka energetyczna i bezpieczeństwo energetyczne, Wyd. Energetyka i Środowisko, Warszawa (2008) 